\title{
DECONSTRUCTION OF THE SYMBOLIC MEANING OF TAYUB SRAGEN DANCE
}

\author{
Septa Suryanto, Mugijatna and Susanto

\section{Indonesia, University Sebelas Maret Surakarta} \\ Author Email: septa suryanto@yahoo.co.id,ykmugijatna@gmail.com, sussastra@gmail.com
}

This is an open access article distributed under the Creative Commons Attribution License, which permits unrestricted use, distribution, and reproduction in any medium, provided the original work is properly cited.

\section{ARTICLE DETAILS}

\section{Article History:}

Received 24 July 2019

Accepted 27 August 2019

Available online 01 October 2019

\section{ABSTRACT}

As a cultural product, Tayub Art can be positioned as a cultural text that must be read to reveal the symbolic meaning contained in it according to the space and time of the meaning (subject). As with the logic of deconstruction in understanding the reality of Tayub Art, the meaning of Tayub Art must be seen as a process and must also be interpreted contextually. This study aims to find out (1) why there was a deconstruction of the symbolic meaning of the Tayub Sragen Art. (2) How to deconstruct the symbolic meaning of Tayub Art that occurs. (3) What are the implications of the deconstruction of the symbolic meaning of the development of Tayub Art. This research was conducted in the realm of cultural studies using qualitative data analysis methods and descriptive and interpretive data analysis techniques that use a hermeneutic approach. The results obtained from this research are the process of deconstruction of the symbolic meaning of Tayub Art for the death of the true meaning of Tayub. In the Mangkunegaran record there is a statement that the nayub is derived from the word tayub which consists of two words, mataya which means dance, and guyub means harmony together. So the meaning of the word tayub with the real meaning is to dance to get along together.

\section{KEYWORDS}

Deconstruction, Meaning, Symbol, Tayub, Sragen.

\begin{abstract}
1. INTRODUCTION
Tayub art is a traditional art that first appeared in the Singosari kingdom. Tayuban as a tradition of the people of East Java, Central Java, and Yogyakarta Special Region. Actually, just a form of dance. Like cokek, which is known in the culture of the Betawi people. In the assumption of cultural anthropology, many cultures are born from a painful historical event. Why do I mention it hurt because the feeling of being depressed as a result of life in the feudal and colonial era was transformed into the form of performing arts. Although from the beginning, tayub was the art of the palace, in its development it had to go out and be degraded into the art of the people, which was increasingly viewed from the side of its pervert, low quality, and tendency to prostitution. Prof. Dr. Suripan Sadi Hutomo (late), philologist and humanist folklore, once described that at a lower level of folk art, tayuban undergoes a change [1-4].
\end{abstract}

This art is called janggrungan, where waranggono (ronggeng, tandak, kledek, taledek, ledek) ngibing among the blandhong (loggers) on the edge of the forest for a living. Cliffort Geertz calls it a street dancer - in Yogyakarta, he is known as a mbarang - which often also plays from house to house or in a crowd. In fact, by tracing the treads of etymological studies there will be contradictory conditions [5,6]. Soegio Pranoto-tayub elders from Nganjuk-meng-kiratabasa-tayub as arranged by ben guyub (arranged to create harmony), a philosophy instilled in tayub as an art for association.

The basic value is the similarity of interests to appreciate the ability, soul, and artistic talent, both the ability as a gamelan musician (pengrawit) or the dancer [7-10]. This similarity will give birth to harmony-serasi tayub as a form of dance; the pounding of the foot in accordance with the sound of the drum, the wave of the hand in rhythm with the xylophone, or the swaying of the head at each blow of the gong.

Tayub is a kind of banquet dance, which is presented to guests at the wedding ceremony of the Javanese community, in Tayuban guests take turns dancing "Tayub" facing a woman tayub dancer who is also called taledhek [11].

\section{FORMULATION OF THE PROBLEM THIS STUDY AIMS TO DETERMINE}

1. Why did the deconstruction of the symbolic meaning of Tayub Sragen Dance occur?

2. How to deconstruct the symbolic meaning of the Tayub dance that occurs?

3. What are the implications of the deconstruction of the symbolic meaning of the development of Tari Tayub?

\section{AIM}

1. To find out the deconstruction of the symbolic meaning of the Tayub Dance of Sragen.

2. To find out the deconstruction of the symbolic meaning of Tayub Dance occurs.

3. To find out the implications of the deconstruction of the symbolic meaning of the development of Tayub dance.

\section{RESEARCH METHODS}

The research titled Deconstruction of the Symbolic Meanings of Tayub Sargen Dance is using qualitative analysis. According to Strauss and Corbin (2003: 4) that a qualitative approach is a type of research that cannot be found through statistical processes and other forms of calculation, but with examples of the study of one's life, history, and behavior, as well as the role of the organization social movements or reciprocal relationships [12].

Furthermore, Branen (2004: 11) argues that in traditional qualitative research, researchers use themselves as instruments, following cultural assumptions. In this case the researcher is expected to be flexible and reflective, but still take distance, in an effort to achieve imaginative insight into the world of respondents. Tradsisi and the approach used in this study according to the researchers' views have the accuracy to explore and obtain more in-depth research results $[13,14]$. 
In the paradigm of the study of culture in the postmodernist space, with a critical thinking space. Thus, theories have functions, including (1) as a tool to clarify a phenomenon that appears at the stage of problem tracking, (2) as a summary tool or data selection tool at the data collection stage, (3) as a tool to sharpen the study at the analysis stage, must be chosen from theories that develop in the ideas of critical theories and adapted to the problem being overcome [15-18].

This study uses a hermeneutic approach to the postmodern paradigm as an action perspective, especially discourse action. Therefore, theoretically research uses one of the branches of clarification from Schleimacher, namely social hermeneutics that directs studies to gain a fundamental understanding of the interrelationships between human persons and their social actions and behaviors, as well as points then going towards the direction and mentality of the intended culture [19-21]

\section{DISCUSSION}

\subsection{Deconstruction of Symbolic Meanings}

Deconstruction of Symbolic Meanings, the concept unit of deconstruction of symbolic meaning consists of three elements, namely deconstruction, meaning, and symbolic. All three are explained as follows. First, deconstruction. Lexically, "deconstruction" is defined as the dismantling of construction and / or reinterpretation of the text (including cultural texts) to reveal the delayed meanings of the text itself.

The meaning of the word from tayub through an article entitled Najub, Najuban; (Baca; Nayub, Nayuban), Poerbotjaroko gives a nayub explanation that is not derived from the word tayub, but comes from the word sayub which means Liquor or also to mention food that is stale; by removing the final letter, it turns into glazed, which in Javanese Krama becomes sajeng, meaning Liquor; because the exchange of "s" becomes " $w "$ turns into wajeng or liquor (Bharatayudha verse II verse 10).

The form of ngoko from wajeng is wayu which is half stale or sliced into tape. In the Mangkunegaran record there is also a statement that the nayub is derived from the word tayub which consists of two words, mataya which means dance, and humor which means mutual harmony. So that it is estimated that the change from two words together: ma-taya and gu-yub become tayub.

The results obtained from this research are the process of deconstruction of the symbolic meaning of Tayub Art for the death of the true meaning of Tayub. In the Mangkunegaran record there is a statement that the nayub is derived from the word tayub which consists of two words, mataya which means dance, and guyub means harmony together. So the meaning of the word tayub with the real meaning is to dance to get along together.

\subsection{The Deconstruction of the Symbolic Meanings of the Tayub Sragen Dance}

The origin of tayub Some experts have argued that tayub according to oral tradition if it is deemed to be chaotic or dictated to be arranged by cikben guyub which means "the dance is well organized so that it becomes a harmony of people". Meanwhile, other opinions say that Tayub said that "Do not use jejogedan and do not get robbed of tledhek", which means having fun dancing with tledhek dancers. In short it can be said that nayub means dancing and others say that nayub means dancing which has something to do with drinking.

\subsection{Implications of deconstruction of the symbolic meaning of the} development of Tayub dance

There are two results of this study; The first deconstruction of the symbolic meaning of the sragen tayub dance that occurs due to metaphysical death which is driven by both aspects; namely (1). Traces of changes in the meaning of the sragen tayub dance art, (2). Tayub dance in the whole (global). Both deconstruction of the symbolic meaning of the tayub sragen dance have two implications (1). Implications for the popularity of sragen tayub dance. (2). Implications for the socio-economic life of tayub sragen.

\subsubsection{Traces of changes in the meaning of tayub sragen dance art}

Tayub sragen has its own metaphysics as a court art in the past and is now an art in the midst of society with a low image in the eyes of the public. In its development, tayub dance is a type of popular social dance that is found in several regions with different names and forms of appearance. In Bali known as Joged, in Banyuwangi known as Gandrung, in West Java it is known as Ronggeng. As tayub folk art was born and developed in traditional society from generation to generation, it lasted for many years, because it had classic characteristics according to the size of the local community.
Tayub Janggrungan is a type of Tayub art that is not bound by dance rules, in shows around from one village to another (ngamen). Then Tayuban can be said to be taller and smoother than Janggrungan, although the tayub dancers can also be Janggrung dancers. Indeed, Tayuban is actually a development of an affair. In Tayuban's performance it is almost the same as Janggrungan but in its implementation it is more subtle and polite and Tayuban is performed on certain occasions such as in village cleaning, marriage ceremonies, and formal events.

\subsubsection{The deconstruction of the symbolic meaning of tayub sragen dance has two implications}

First; The deconstruction of the symbolic meaning of tayub dance in the whole (Global), performance art is always present in the implementation of village clean ceremonies, Nyadran, ruwatan ceremonies and many more. One of the folks performing arts that functions in the ritual is tayub. At the earth surgical ceremony, pengibing or penjoget which appeared first with tledhek tayub were village elders. Pairing between village elders and tledhek in the dance is called earth surgery or dissecting the earth. The pairing dance also symbolized the relationship between men and women with the land dissected or split to plant rice. In other words, dividing the woman's womb is intended / interpreted as dividing the earth.

Second; Implications for the socio-economic life of tayub sragen. Implications for the socio-economic life of tayub sragen, Tledhek are considered to have meaning for the supporting community that is able to tie kinship between the responders. When he performed with other art groups, he was able to tie kinship between the responders. Tledhek and the group can lift the image or dignity that has work in its supporters.

\section{CONCLUSIONS}

Tayub Sragen is a kind of banquet dance, which is presented to guests at the wedding ceremony of the Javanese community, in Tayuban guests take turns dancing "Tayub" facing a woman tayub dancer who is also called taledhek. Then this raises a question with the emergence of the Deconstruction of the Symbolic Meanings of the Sragen tayub dance, with the intention of exposing the meanings of the tayub name and tayub meanings globally as well as the socio-economic life of the dancer.

\section{REFERENCES}

[1] Mufrihah. 2018. Fungsi Dan Makna Simbolik Kesenian Jaranan Jur Ngasinan Desa Sukorejo Kecamatan Sutojayan Kabupaten Blitar, Jurnal ISI Denpasar.

[2] Nimita. 2017. The Art Creation in The Tradisional Art Area, Jurnal Seni Budaya.

[3] Noordiana. 2016. The Impact of Tayub Exploitation on The Tradition and Life of Javanese Sosiety, Jurnal Harmoni, Department of Drama, Dance and Music, UNNES.

[4] Hidayat, R. 2014. The Popularity of Waranggana Tayub Malang Trough Body Exploitation, Jurnal Harmoni, Department Drama, Dance and Music UNNES.

[5] Suryani. 2014. Tayub as a Symbolic Interaction Medium In Sedekah Bumi Ritual In Pati Regency, Jurnal Harmoni, Department of Drama, Dance and Music, UNNES.

[6] Miftahus, S. 2003. Perempuan Tayub: Nasibmu di Sana, Nasibmu di Sini. Jurnal Srintil Media Perempuan Multikultural.

[7] Kutha, R.I.N. 2007. Sastra Dan Cultural Studies: Representasi Fiksi dan Fakta. Yogyakarta: Pustaka Pelajar.

[8] Setya Yuwono, S. 1996. (ed), Tradisi dari Blora, (Semarang: Citra Almamater, 1996)

[9] Widyastutieningrum, S.R. 2007. TAYUB di Blora Jawa Tengah Pertunjukan Ritual Kerakyatan, (Surakarta: ISI Press Surakarta, 2007).

[10] Suara Merdeka. 1992, Koleksi Reksa Poestaka Mangkunegaran, 431.

[11] Majalah Nova. 1989, Koleksi Reksa Poestaka Mangkunegaran, 291.

[12] Hananta. 1993. Usaha Pelestarian Seni Tari Tayub Wonogiri (Studi Kasus Tentang Perkembangan Kesenian Tari Tradisional di Kabupaten Wonogiri), Skripsi Fakultas Sastra dan Seni Rupa UNS. 
[13] Awiroto, W. 1989. Kesenian Tayub Dalam Upacara Bersih Desa Di Desa Karangsari Kecamatan Semin, Kabupaten Gunung Kidul, Skripsi Fakultas Sastra dan Seni Rupa UNS.

[14] Subur, D. 1996 Tari Tayub Garapan Baru Departemen Pendidikan Dan Kebudayaan Kabupaten Sragen (Sebuah Tinjauan Analisis Garap Gerak), Skripsi Fakultas Karawitan Institut Seni Indonesia Surakarta.

[15] Pitana, P. 2014. Teori Sosial Kritis: Metode Dan Aplikasinya, (STAIN Press Purwokerto).

[16] Piliang, Y.A. 2010. Semiotika Dan Hipersemiotika: kode, gaya, \& matinya makna, (Bandung: Matahari).
[17] Barker, C. 2005. Cultural Studies Teori Dan Praktik, (Yogyakarta: BENTANG (PT. Bentang Pustaka).

[18] Wayan. S.I. 2009. Impian Untuk Desa Pakraman, Artikel. Majalah Sarad, 110.

[19] Syinnot, A. 2007. Tubuh Sosial: Simbolisme, Diri, dan Masyarakat, Yogyakarta: Jalasutra.

[20] Ardhie, R. 2014. Sosiologi Tubuh. Yogyakarta: Penerbit Kaukaba.

[21] Raffles, T.S. 2014. The History of Java. Yogyakarta: PT Narasi. 